\title{
Article
}

\section{The Effect of Precursor Concentration on the Particle Size, Crystal Size, and Optical Energy Gap of $\mathrm{Ce}_{\mathrm{x}} \mathrm{Sn}_{1-x} \mathrm{O}_{2}$ Nanofabrication}

\author{
Naif Mohammed Al-Hada 1,2,3,*(1), Rafiziana Md. Kasmani ${ }^{2}$, Hairoladenan Kasim ${ }^{4, *}$, Abbas M. Al-Ghaili ${ }^{5, *}$, \\ Muneer Aziz Saleh ${ }^{2}$, Essam M. Banoqitah ${ }^{6}$, Abdulsalam M. Alhawsawi ${ }^{6,7} \mathbb{1}$, Anwar Ali Baqer ${ }^{8}$, Jian Liu ${ }^{1}$, \\ Shicai Xu ${ }^{1}$, Qiang Li ${ }^{1}$, Azlan Muhammad Noorazlan ${ }^{9}$, Abdullah A. A. Ahmed ${ }^{3,10}$, Moayad Husein Flaifel ${ }^{11,12}$, \\ Suriati Paiman ${ }^{13} \mathbb{D}$, Nazirul Nazrin ${ }^{13}$, Bandar Ali Al-Asbahi ${ }^{14}$ and Jihua Wang ${ }^{1, *}$
}

\section{check for} updates

Citation: Al-Hada, N.M.; Md. Kasmani, R.; Kasim, H.; Al-Ghaili, A.M.; Saleh, M.A.; Banoqitah, E.M.; Alhawsawi, A.M.; Baqer, A.A.; Liu, J.; $\mathrm{Xu}, \mathrm{S}$;; et al. The Effect of Precursor Concentration on the Particle Size, Crystal Size, and Optical Energy Gap of $\mathrm{Ce}_{\mathrm{x}} \mathrm{Sn}_{1-\mathrm{x}} \mathrm{O}_{2}$ Nanofabrication. Nanomaterials 2021, 11, 2143. https:// doi.org/10.3390/nano11082143

Academic Editor: Sotirios Baskoutas

Received: 15 July 2021

Accepted: 14 August 2021

Published: 22 August 2021

Publisher's Note: MDPI stays neutral with regard to jurisdictional claims in published maps and institutional affiliations.

Copyright: (c) 2021 by the authors. Licensee MDPI, Basel, Switzerland. This article is an open access article distributed under the terms and conditions of the Creative Commons Attribution (CC BY) license (https:/ / creativecommons.org/licenses/by/ $4.0 /)$.
1 Shandong Key Laboratory of Biophysics, Institute of Biophysics, Dezhou University, Dezhou 253023, China; liujian.cn@live.com (J.L.); shicaixu@dzu.edu.cn (S.X.); qiangli_chem@hotmail.com (Q.L.)

2 School of Chemical and Energy Engineering, Universiti Teknologi Malaysia, Skudai, Johor Bahru 81310, Malaysia; rafiziana@utm.my (R.M.K.); mouneersaleh@yahoo.com (M.A.S.)

3 Department of Physics, Faculty of Applied Science, Thamar University, Dhamar 87246, Yemen; abdullah2803@gmail.com

4 College of Computing \& Informatics (CCI), Universiti Tenaga Nasional (UNITEN), Kajang 43000, Malaysia

5 Institute of Informatics and Computing in Energy (IICE), Universiti Tenaga Nasional (UNITEN), Kajang 43000, Malaysia

6 Department of Nuclear Engineering, Faculty of Engineering, K. A. CARE Energy Research and Innovation Center, King Abdulaziz University, P.O. Box 80204, Jeddah 21589, Saudi Arabia; ebanoqitah@kau.edu.sa (E.M.B.); amalhawsawi@kau.edu.sa (A.M.A.)

7 Center for Training \& Radiation Prevention, King Abdulaziz University, P.O. Box 80204, Jeddah 21589, Saudi Arabia

8 Department of Physics, Faculty of Science for Women, University of Baghdad, Baghdad 10071, Iraq; anwaralibaqerkram@yahoo.com

9 Physics Department, Faculty of Science and Mathematics, University Pendidikan Sultan Idris, Tanjong Malim 35900, Malaysia; Azlanmn@fsmt.upsi.edu.my

10 Fachbereich Physik, Center for Hybrid Nanostructures (CHyN), Universität Hamburg, 20146 Hamburg, Germany

11 Department of Physics, College of Science, Imam Abdulrahman Bin Faisal University, P.O. Box 1982, Dammam 31441, Saudi Arabia; physci2007@gmail.com

12 Basic and Applied Scientific Research Center, College of Science, Imam Abdulrahman Bin Faisal University, P.O. Box 1982, Dammam 31441, Saudi Arabia

13 Department of Physics, Faculty of Science, University Putra Malaysia, Serdang 43400, Malaysia; suriati@upm.edu.my (S.P.); nazirulnazrin@ymail.com (N.N.)

14 Department of Physics \& Astronomy, College of Science, King Saud University, P.O. Box 2455, Riyadh 11451, Saudi Arabia; balasbahi@ksu.edu.sa

* Correspondence: naifalhada@yahoo.com (N.M.A.-H.); hairol@uniten.edu.my (H.K.); abbas@uniten.edu.my (A.M.A.-G.); jhw25336@126.com (J.W.)

Abstract: In the present work, a thermal treatment technique is applied for the synthesis of $\mathrm{Ce}_{\mathrm{x}} \mathrm{Sn}_{1-\mathrm{x}} \mathrm{O}_{2}$ nanoparticles. Using this method has developed understanding of how lower and higher precursor values affect the morphology, structure, and optical properties of $\mathrm{Ce}_{\mathrm{x}} \mathrm{Sn}_{1-\mathrm{x}} \mathrm{O}_{2}$ nanoparticles. $\mathrm{Ce}_{\mathrm{x}} \mathrm{Sn}_{1-\mathrm{x}} \mathrm{O}_{2}$ nanoparticle synthesis involves a reaction between cerium and tin sources, namely, cerium nitrate hexahydrate and tin (II) chloride dihydrate, respectively, and the capping agent, polyvinylpyrrolidone (PVP). The findings indicate that lower $x$ values yield smaller particle size with a higher energy band gap, while higher $x$ values yield a larger particle size with a smaller energy band gap. Thus, products with lower $x$ values may be suitable for antibacterial activity applications as smaller particles can diffuse through the cell wall faster, while products with higher $\mathrm{x}$ values may be suitable for solar cell energy applications as more electrons can be generated at larger particle sizes. The synthesized samples were profiled via a number of methods, such as scanning electron microscopy (SEM), transmission electron microscopy (TEM), X-ray diffraction (XRD), and Fourier transform infrared spectroscopy (FT-IR). As revealed by the XRD pattern analysis, the $\mathrm{Ce}_{\mathrm{x}} \mathrm{Sn}_{1-\mathrm{x}} \mathrm{O}_{2}$ 
nanoparticles formed after calcination reflect the cubic fluorite structure and cassiterite-type tetragonal structure of $\mathrm{Ce}_{x} \mathrm{Sn}_{1-\mathrm{x}} \mathrm{O}_{2}$ nanoparticles. Meanwhile, using FT-IR analysis, Ce-O and Sn-O were confirmed as the primary bonds of ready $\mathrm{Ce}_{x} \mathrm{Sn}_{1-\mathrm{x}} \mathrm{O}_{2}$ nanoparticle samples, whilst TEM analysis highlighted that the average particle size was in the range $6-21 \mathrm{~nm}$ as the precursor concentration $\left(\mathrm{Ce}\left(\mathrm{NO}_{3}\right)_{3} \cdot 6 \mathrm{H}_{2} \mathrm{O}\right)$ increased from 0.00 to 1.00 . Moreover, the diffuse UV-visible reflectance spectra used to determine the optical band gap based on the Kubelka-Munk equation showed that an increase in $\mathrm{x}$ value has caused a decrease in the energy band gap and vice versa.

Keywords: $\mathrm{Ce}_{x} \mathrm{Sn}_{1-\mathrm{x}} \mathrm{O}_{2}$ nanoparticles; thermal treatment technique; polyvinylpyrrolidone; energy band gap

\section{Introduction}

Recently, nanomaterials have been the focus of extensive research studies, with their unique physiochemical properties attracting particular attention [1-6]. As a result of such studies, new systems, nanoplatforms, devices, and structures applicable to various domains have been developed [7-10]. The proliferation of related work makes nanomaterial applications demonstrating biodegradability, biocompatibility, and functionalization especially advantageous [11,12]. Empirical research has been significantly concerned with the use of cubic fluorite structures $\left(\mathrm{CeO}_{2}\right)$ and cassiterite-type tetragonal structures of $\left(\mathrm{SnO}_{2}\right)$ semiconductors nanomaterials $[4,13,14]$. Both group II and group IV elements are included in the $\mathrm{CeO}_{2}$ cubic fluorite structure, since it is classified as II-IV composite semiconductor [14]. There are various applications intended to exploit the singular structural features of nanomaterials on the basis of the useful chemical and physical properties [15]. It has a notable structure with a cubic fluorite structure crystalline, along with energy band gaps amounting to 3.0-3.6 eV [16]. $\mathrm{CeO}_{2}$ semiconductor nanostructures have wide applications, such as in photovoltaic and solar cells [17,18]. Further significant applications include diodes, clear electrodes, gas sensors, as well as antibacterial activity [19]. $\mathrm{CeO}_{2}$ nanostructures have been prepared in different shapes, such as nanoparticles [16], nanocrystals [20], nanoclusters [21], nanowires [22], nanotubes [23], and nanoflowers.

Similarly, the composite semiconductor (II-VI) $\mathrm{SnO}_{2}$-type tetragonal structure is made up of the metal Sn (II) and non-metallic elemental oxygen (VI) [4,13]. Important applications have been devised based on the remarkable properties presented by various $\mathrm{SnO}_{2}$ semiconductor materials [24]. Used as the archetypal tetragonal crystal structure, this material is categorized as an n-type semiconductor with $3.6 \mathrm{eV}$ band gaps [25]. Research and applications have sought to exploit the characteristic properties of $\mathrm{SnO}_{2}$ nanomaterials rooted in their singular crystal structure and nano-sized dimensions. Thus, applications are exemplified by solar cells due to their tunable physical and chemical properties, with enhanced performance over their bulk counterparts [26,27], and optoelectronic devices [28], with applications geared towards leveraging the pellucidity occurring in the visible solar spectrum zone, as well as catalysis [29], diodes [30], gas sensors [31], and biomedical tools [32]. Furthermore, nanocrystals [33], nanoclusters [34], nanotubes [35], and nanorods [36] are among the wide range of $\mathrm{SnO}_{2}$ nanomaterials produced via different approaches, such as sonochemical [37], solvothermal [26], co-precipitation [38], microwave hydrothermal [39], and sol-gel treatment [40] approaches.

The complementary features are indicated by the distinguishing composition of $\mathrm{Ce}_{\mathrm{x}} \mathrm{Sn}_{1-\mathrm{x}} \mathrm{O}_{2}$ with regard to the bandgaps and sizes that grow from both oxide semiconductors. It is also probable that it has characteristics that set it apart from singular semiconductor constituents. The use of $\mathrm{Ce}_{x} \mathrm{Sn}_{1-\mathrm{x}} \mathrm{O}_{2}$ for various purposes, including biocides and disinfectants is a matter that warrants attention in relation to the particular $\mathrm{Ce}_{\mathrm{x}} \mathrm{Sn}_{1-\mathrm{x}} \mathrm{O}_{2}$ nanocomposite composition. The composition displays better stability and a lengthier life than organic-based materials, not to mention the fact that it has been the focus of more extensive study with regard to biological activity [41,42]. Precipitation meth- 
ods [43], co-precipitation methods [44], and the hydrothermal strategies [45] are among the techniques through which it is possible to produce $\mathrm{Ce}_{x} \mathrm{Sn}_{1-\mathrm{x}} \mathrm{O}_{2}$ nanostructures. Nevertheless, due to the complexity of the process of synthesis, which involves extensive reaction times, toxic reagents, and effluent byproducts, such techniques are not highly effective for the industrial-scale production of $\mathrm{Ce}_{x} \mathrm{Sn}_{1-\mathrm{x}} \mathrm{O}_{2}$ nanoparticles. Moreover, the synthesis of $\mathrm{Ce}_{\mathrm{x}} \mathrm{Sn}_{1-\mathrm{x}} \mathrm{O}_{2}$ nanoparticles at various $\mathrm{x}$ values has not been investigated. More specifically, an uncomplicated heat treatment technique may be adopted to avoid waste $\mathrm{Ce}_{x} \mathrm{Sn}_{1-\mathrm{x}} \mathrm{O}_{2}$ nanoparticle products. The significance of this work stems from the fact that it proposes a production method compatible with industrial applications that is capable of yielding products defined by basic handling, particle size regulation (smaller and larger sizes are respectively suitable for antibacterial activity due to the smaller particle can diffuse through the cell wall faster, and energy applications due to more electrons can be generated at the bigger particle size [6]), inexpensiveness, high quality, high adaptability, a powdered form, and effective band gap. The chosen approach is also advantageous because it does not generate toxic byproducts and does not require extra chemical reagents. On the basis of this approach, this work seeks to determine how precursor values affect $\mathrm{Ce}_{\mathrm{x}} \mathrm{Sn}_{1-\mathrm{x}} \mathrm{O}_{2}$ nanoparticles.

$\mathrm{Ce}_{x} \mathrm{Sn}_{1-x} \mathrm{O}_{2}$ samples have been synthesized in this work utilizing a thermal-based treatment process and the effects of $\mathrm{Ce}$ and $\mathrm{Sn}$ contents on the morphological, structural, and optical properties of $\mathrm{Ce}_{\mathrm{x}} \mathrm{Sn}_{1-\mathrm{x}} \mathrm{O}_{2}$ nanoparticles have also been analyzed. The approach has involved the use of a solution with a content of metal ions and polyvinylpyrrolidone acting as precursor and capping agents, respectively. Furthermore, to obtain the desired pure nanoparticles, a calcination technique has been adopted, while various methods are applied to investigate morphology and crystallinity. The effect of $x$ value variation is investigated as well.

\section{Materials and Methods}

\subsection{Materials}

Cerium nitrate hexahydrate with a purity of more than $99 \%\left(\mathrm{Ce}\left(\mathrm{NO}_{3}\right)_{3} \cdot 6 \mathrm{H}_{2} \mathrm{O}\right)$ and tin (II) chloride dihydrate $\left(\mathrm{SnCl}_{2} \cdot 2 \mathrm{H}_{2} \mathrm{O}\right)$, both in concentrations of $0.00,0.20,0.40,0.60,0.80$, and $1.00 \mathrm{mmol}$, were employed as the metal precursors, while polyvinylpyrrolidone and deionized water served as a capping agent, which mediated the spread of particles, and as solvent, respectively. All the chemicals were acquired from Sigma-Aldrich (US), their quality was research-grade, and none were purified further.

\subsection{Synthesis of Samples}

The preparation of the $\mathrm{Ce}_{x} \mathrm{Sn}_{1-\mathrm{x}} \mathrm{O}_{2}$ nanoparticle product involved the dissolution of $4.5 \mathrm{~g}$ of polyvinylpyrrolidone into $100 \mathrm{~mL}$ of deionized water, followed by energetic stirring for $120 \mathrm{~min}$ at a temperature of $70{ }^{\circ} \mathrm{C}$. The next step was the dissolution of Ce $\left(\mathrm{NO}_{3}\right)_{3} \cdot 6 \mathrm{H}_{2} \mathrm{O}$ into amounts of $0.00,0.20,0.40,0.60,0.80$, and $1.00 \mathrm{mmol}$. A homogeneous solution was obtained by adding and energetically mixing $\mathrm{SnCl}_{2} \cdot 2 \mathrm{H}_{2} \mathrm{O}$ in amounts of 1.00 , $0.80,0.60,0.40,0.20$, and $0.00 \mathrm{mmol}$. The combined solution was placed on a petri dish and subjected to drying in an oven for one day at $80^{\circ} \mathrm{C}$. In this way, a solid was attained which was then rendered into a powdered form through crushing for half an hour in a mortar. A box furnace was subsequently employed to subject the powder to calcination at $650{ }^{\circ} \mathrm{C}$ for an hour and a half. Once the synthesized and calcined oxide nanoparticle samples were obtained, their profiling could be initiated.

\section{Results and Discussion}

\subsection{Mechanism of the Formation of the Nanoparticle}

Figure 1a presents the chemical structure of the amphiphilic PVP, in which the head group is the pyrrolidone part (hydrophilic) while the tail group is the polyvinyl part (hydrophobic); however, when the PVP molecules are in an aqueous solution, the structure may transform to a resonance structure as illustrated in Figure 1b [46]. Figure 2 schemati- 
cally shows the process of interaction between the capping agent PVP and the metal ions. The cerium and tin are bound by strong ionic bonds between the metallic ions and the amide groups of the polymer chains. At the same time, cerium and tin ions are already bound to nitrate ions $\left(\mathrm{NO}_{3}{ }^{-}\right)$and the propane-2-olate ions $\left(\mathrm{OC}_{3} \mathrm{H}_{7}{ }^{-}\right)$, respectively, via a strong ionic bond. Eventually, the metal cations are immobile in the cavities of the polymer chains, which leads to the formation of uniformly distributed metal oxides in a solid solution in the drying and calcination process [47].

a)

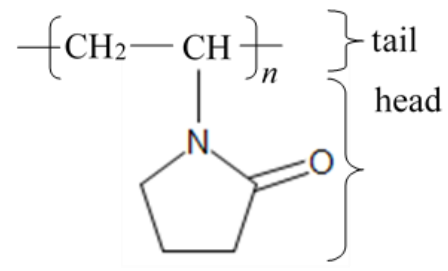

b)

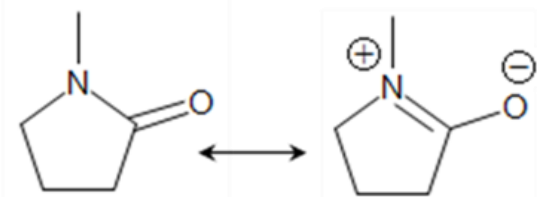

Figure 1. (a) PVP chemical structure; (b) formation of the resonance structure of the pyrene ring of PVP.

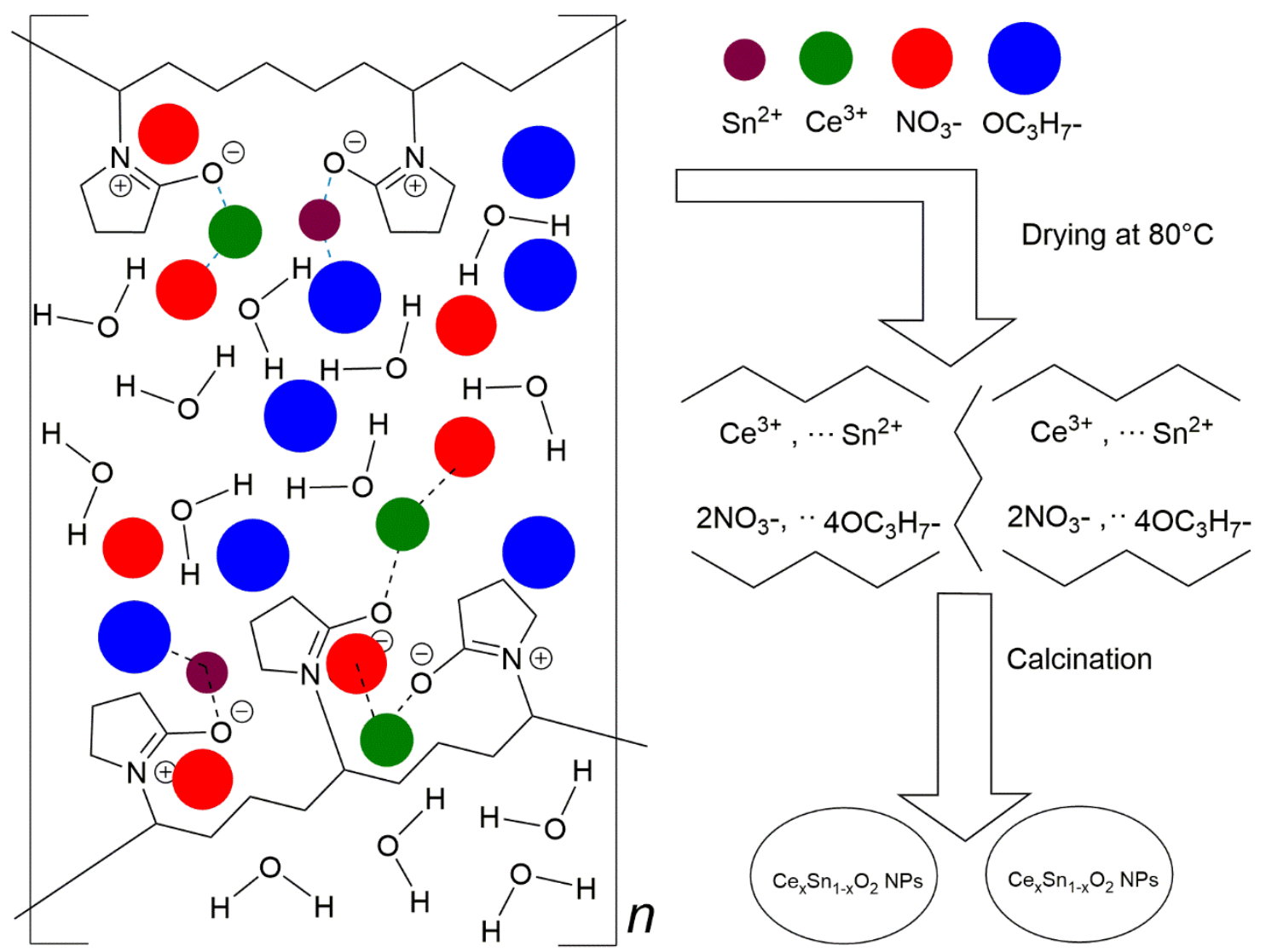

Figure 2. Schematic illustration of the proposed mechanism of interaction between metal ions and PVP.

PVP's main role in the employed method is to control the growth of the particles by forming passivation layers around the metal. In addition, the functions of PVP during the preparation of $\mathrm{Ce}_{\mathrm{x}} \mathrm{Sn}_{1-\mathrm{x}} \mathrm{O}_{2}$ nanoparticles are to regulate the expansion nucleation of nanoparticles, limit the accretion of the nanoparticles, improve the degree of crystallinity of the nanoparticles, create a restricted environment around the $\mathrm{Ce}_{x} \mathrm{Sn}_{1-\mathrm{x}} \mathrm{O}_{2}$ nanoparticles, and facilitate the development of nanoparticles with a homogenous dispersal of both size and form $[47,48]$. The drying process may decompose the PVP partly to feature shorter polymer chains $[49,50]$. The shortening of polymer chains causes the metallic ions to be well dispersed throughout the PVP cavities and a reduction in the number of metal ions that 
are being capped. The effect of PVP is not restricted only to the solution and drying steps, but also the formation of $\mathrm{Ce}_{x} \mathrm{Sn}_{1-x} \mathrm{O}_{2}$ nanoparticles in the calcination process through the nucleation, solid-state reaction, and the oxidization of $\mathrm{Ce}^{3+}$ and $\mathrm{Sn}^{2+}$ ions. In addition, during the calcination process, organic materials (PVP) are being eliminated, which causes steric hindrance disruption.

\subsection{TEM Analysis}

Transmission electron microscopy (TEM) was the basis for profiling the nanoparticle samples. This method is particularly useful because it ensures that the generated nanoparticles have a homogeneous round shape and size. Samples typically display uniformity in term of morphological features $\left(\mathrm{x}_{0.00}-\mathrm{x}_{1.00}\right)$. $\mathrm{Ce}_{\mathrm{x}} \mathrm{Sn}_{1-\mathrm{x}} \mathrm{O}_{2}$ nanoparticles were subjected to calcination at $650{ }^{\circ} \mathrm{C}$ and their TEM images and particle size distributions are illustrated in Figures 3 and 4, respectively. These images indicate that the existence of direct proportionality between the $x$ values and particle size, with the increase in particle size being determined by contiguous particle aggregation, which in turn is caused by surface melting at elevated calcination temperature and $x$ values.
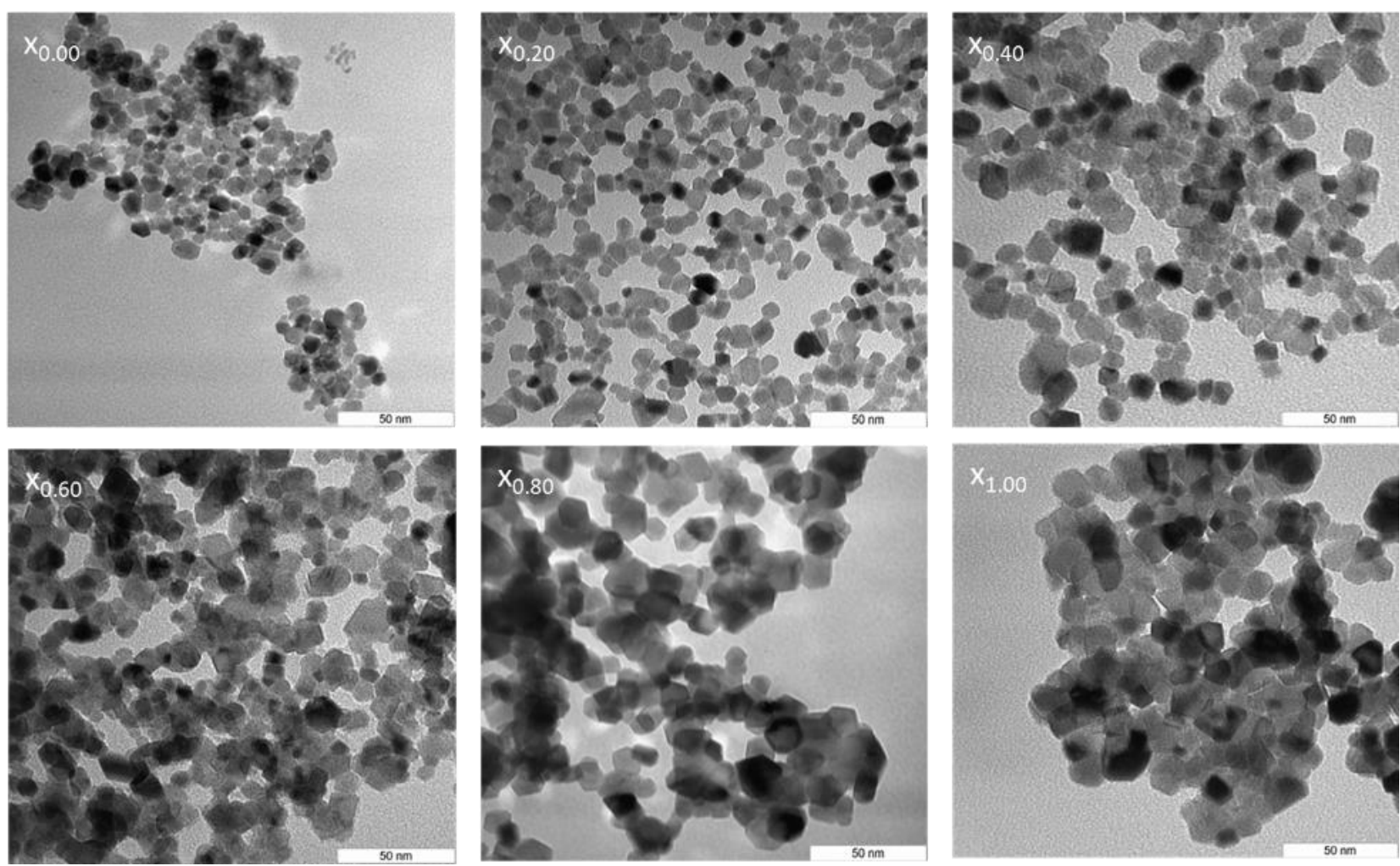

Figure 3. TEM images of $\left(\mathrm{x}_{0.00}\right) \mathrm{Ce}_{0.00} \mathrm{Sn}_{1.00} \mathrm{O}_{2},\left(\mathrm{x}_{0.20}\right) \mathrm{Ce}_{0.20} \mathrm{Sn}_{0.80} \mathrm{O}_{2},\left(\mathrm{x}_{0.40}\right) \mathrm{Ce}_{0.40} \mathrm{Sn}_{0.60} \mathrm{O}_{2},\left(\mathrm{x}_{0.06}\right) \mathrm{Ce}_{0.60} \mathrm{Sn}_{0.40} \mathrm{O}_{2},\left(\mathrm{x}_{0.08}\right)$ $\mathrm{Ce}_{0.80} \mathrm{Sn}_{0.20} \mathrm{O}_{2}$ and $\left.\left(\mathrm{x}_{1.00}\right) \mathrm{Ce}_{1.00} \mathrm{Sn}_{0.00} \mathrm{O}_{2}\right)$ nanoparticles calcined at $650{ }^{\circ} \mathrm{C}$.

The size uniformity and round shape of the $\mathrm{Ce}_{x} \mathrm{Sn}_{1-\mathrm{x}} \mathrm{O}_{2}$ nanoparticles were confirmed by the results obtained. The standard process of nanoparticle sample production was established to be effective, with the sizes of the nanoparticles being influenced by the presence of PVP in a considerable amount based on the agglomeration and suppression mechanism [51]. The outcomes of the XRD and TEM analyses, obtained from the differently sized nanoparticles (from $6 \mathrm{~nm}$ to $21 \mathrm{~nm}$ ), synthesized at $650{ }^{\circ} \mathrm{C}$ by increasing the $\mathrm{x}$ value, are outlined in Table 1. PVP is used as a stabilizer for particles and mediates nanoparticle nucleation and formation while also contributing to homogeneity [52-55]. As such, it is useful for restricting nanoparticle size, as well as for preventing nanoparticle aggregation [13,56-59]. Consequently, the particles increased in size when $\mathrm{CeO}_{2}$ was used in the sample $(x=0.20-1.00)$ due to the intensified agglomeration. Meanwhile, the 
reduction trend could be attributed to the fact that $\mathrm{Ce}^{3+}$ and $\mathrm{Sn}^{2+}$ have different ionic crystal radii.
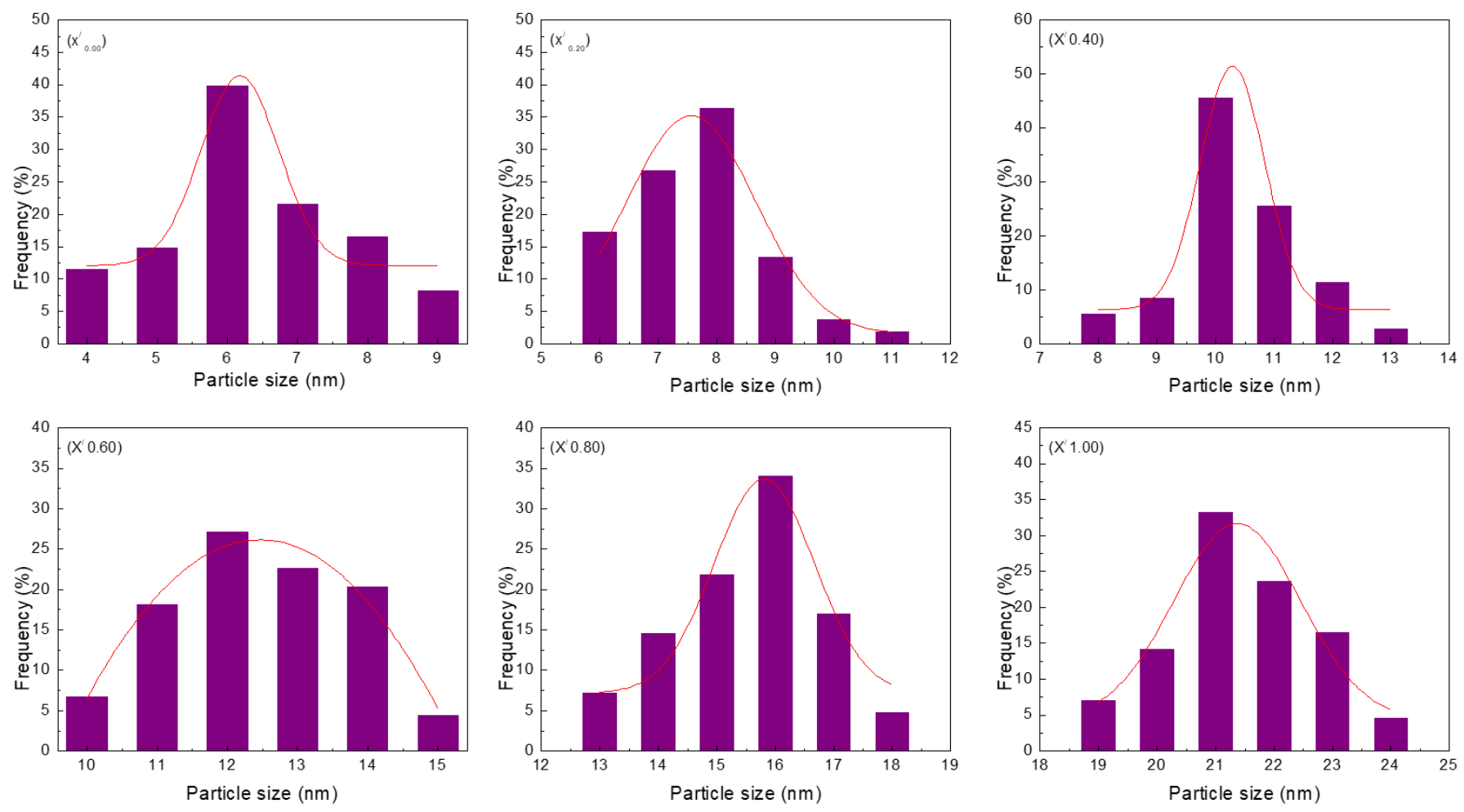

Figure 4. Particle size distribution of $\left(\mathrm{x}^{\prime}{ }_{0.00}\right) \mathrm{Ce}_{0.00} \mathrm{Sn}_{1.00} \mathrm{O}_{2},\left(\mathrm{x}^{\prime}{ }_{0.20}\right) \mathrm{Ce}_{0.20} \mathrm{Sn}_{0.80} \mathrm{O}_{2}$, ( $\left.\mathrm{x}^{\prime}{ }_{0.40}\right) \mathrm{Ce}_{0.40} \mathrm{Sn}_{0.60} \mathrm{O}_{2}$, ( $\left.\mathrm{x}^{\prime}{ }_{0.06}\right)$ $\mathrm{Ce}_{0.60} \mathrm{Sn}_{0.40} \mathrm{O}_{2},\left(\mathrm{x}^{\prime}{ }_{0.08}\right) \mathrm{Ce}_{0.80} \mathrm{Sn}_{0.20} \mathrm{O}_{2}$, and $\left.\left(\mathrm{x}^{\prime}{ }_{1.00}\right) \mathrm{Ce}_{1.00} \mathrm{Sn}_{0.00} \mathrm{O}_{2}\right)$ nanoparticles calcined at $650{ }^{\circ} \mathrm{C}$.

Table 1. XRD and TEM results for $\mathrm{Ce}_{\mathrm{x}} \mathrm{Sn}_{1-\mathrm{x}} \mathrm{O}_{2}$ nanoparticles of various $\mathrm{x}$ values when synthesized at $650{ }^{\circ} \mathrm{C}$.

\begin{tabular}{ccccc}
\hline x Values & $\begin{array}{c}\text { Sample Concentrations } \mathrm{Ce}_{\mathbf{x}} \mathbf{S n}_{\mathbf{1 - x}} \mathbf{O}_{\mathbf{2}} \text { At } \\
\mathbf{6 5 0}{ }^{\circ} \mathbf{C} \text { and } \mathbf{4 . 5} \mathbf{~ g m} \text { of PVP }\end{array}$ & $\begin{array}{c}\text { Particle Size } \\
\text { by TEM (nm) }\end{array}$ & $\begin{array}{c}\text { Crystallite Size } \\
\text { by XRD (nm) }\end{array}$ & $\begin{array}{c}\text { Energy Bandgap } \\
(\mathbf{e V})\end{array}$ \\
\hline 0.00 & $\mathrm{Ce}_{0.00} \mathrm{Sn}_{1.00} \mathrm{O}_{2}$ & $6 \pm 2$ & 6 & 3.97 \\
\hline 0.20 & $\mathrm{Ce}_{0.20} \mathrm{Sn}_{0.80} \mathrm{O}_{2}$ & $8 \pm 3$ & 7 & 3.86 \\
\hline 0.40 & $\mathrm{Ce}_{0.40} \mathrm{Sn}_{0.60} \mathrm{O}_{2}$ & $10 \pm 2$ & 10 & 3.72 \\
\hline 0.60 & $\mathrm{Ce}_{0.60} \mathrm{Sn}_{0.40} \mathrm{O}_{2}$ & $12 \pm 4$ & 14 & 3.64 \\
\hline 0.80 & $\mathrm{Ce}_{0.80} \mathrm{Sn}_{0.20} \mathrm{O}_{2}$ & $16 \pm 3$ & 19 & 3.56 \\
\hline 1.00 & $\mathrm{Ce}_{1.00} \mathrm{Sn}_{0.00} \mathrm{O}_{2}$ & $21 \pm 2$ & & 3.40 \\
\hline
\end{tabular}

\subsection{SEM Analysis}

The morphologies of $\mathrm{Ce}_{\mathrm{x}} \mathrm{Sn}_{1-\mathrm{x}} \mathrm{O}_{2}$ nanoparticles have been analyzed using scanning electron microscopy (SEM). Figure 5 illustrates micrographs associated with the $\mathrm{Ce}_{\mathrm{x}} \mathrm{Sn}_{1-\mathrm{x}} \mathrm{O}_{2}$ nanoparticles at every $\mathrm{x}$ value. The shapes of the prepared samples were almost spherical with regularities at $x=1.00$, while the samples featured small grains and were spherical at $x=0.00$. This finding was consistent with those reported in earlier studies $[13,60]$. In Figure 5, the images for $x=0.20$ and $x=0.80$ show samples of clusters formed with a round shape due to the fusion, breakdown, and overlapping of grains caused by the reduction in $x$ value. Small particles agglomerated on large particles as shown in images where $x=0.60$ and $x=0.80$, due to the decreased amount of $\mathrm{SnO}_{2}$ that caused an agglomeration of $\mathrm{SnO}_{2}$ on $\mathrm{CeO}_{2}$. 

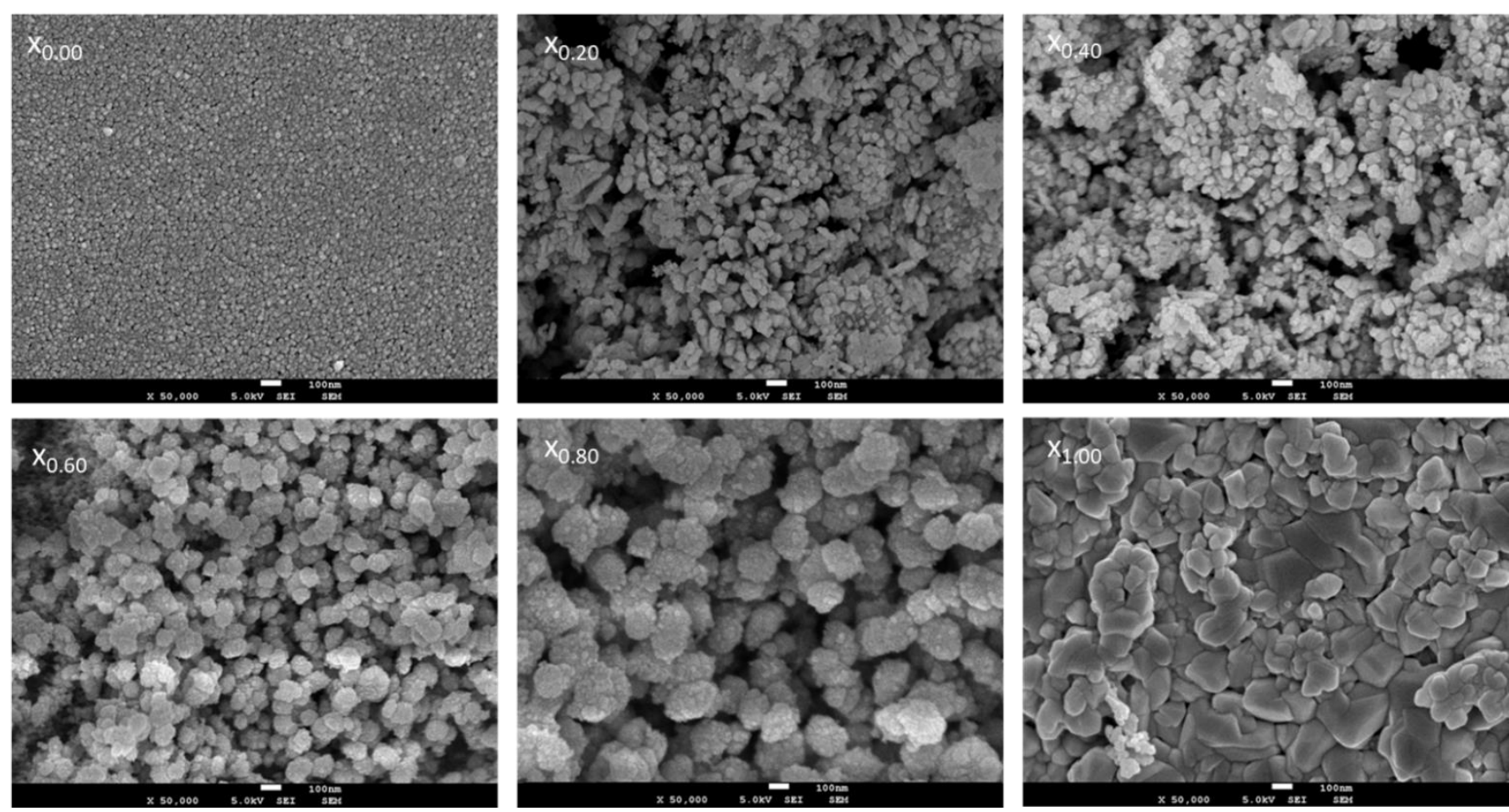

Figure 5. SEM images of $\left(\mathrm{x}_{0.00}\right) \mathrm{Ce}_{0.00} \mathrm{Sn}_{1.00} \mathrm{O}_{2},\left(\mathrm{x}_{0.20}\right) \mathrm{Ce}_{0.20} \mathrm{Sn}_{0.80} \mathrm{O}_{2},\left(\mathrm{x}_{0.40}\right) \mathrm{Ce}_{0.40} \mathrm{Sn}_{0.60} \mathrm{O}_{2},\left(\mathrm{x}_{0.06}\right) \mathrm{Ce}_{0.60} \mathrm{Sn}_{0.40} \mathrm{O}_{2},\left(\mathrm{x}_{0.08}\right)$ $\mathrm{Ce}_{0.80} \mathrm{Sn}_{0.20} \mathrm{O}_{2}$ and $\left.\left(\mathrm{x}_{1.00}\right), \mathrm{Ce}_{1.00} \mathrm{Sn}_{0.00} \mathrm{O}_{2}\right)$ nanoparticles calcined at $650{ }^{\circ} \mathrm{C}$.

\subsection{XRD Analysis}

The XRD patterns correlated with the $\mathrm{Ce}_{\mathrm{x}} \mathrm{Sn}_{1-\mathrm{x}} \mathrm{O}_{2}$ nanoparticles after $180 \mathrm{~min}$ of calcination at $650{ }^{\circ} \mathrm{C}$ are shown in Figure $6\left(\mathrm{x}_{0.00}-\mathrm{x}_{1.00}\right)$, with the diffraction peak associated with $\mathrm{SnO}_{2}$ nanoparticles being denoted by the plus symbol, while the diffraction peak for the $\mathrm{CeO}_{2}$ nanoparticles is denoted by the star symbol. In the context of XRD patterns, the diffraction peaks represent standard values equivalent to the $\mathrm{SnO}_{2}$ and $\mathrm{CeO}_{2}$ compounds with tetragonal and cubic fluorite structures, respectively. The peaks associated with the $\mathrm{SnO}_{2}$ nanoparticles correspond to the (110), (011), (020), (121), (220), (002), (130), (112), (031), (022), and (231) planes, which is in agreement with JCPDS 00-041-1445 [4]. Meanwhile, the peaks associated with the $\mathrm{CeO}_{2}$ nanoparticles correspond to the (1 111$),\left(\begin{array}{lll}2 & 0 & 0\end{array}\right),\left(\begin{array}{ll}2 & 2\end{array}\right)$ ), (3 1 1), (2 2 2), (4 0 0), (3 3 1), and (4 20 ) planes, which is consistent with the PDF Card No: 34-0394 data [14]. Furthermore, a mixture of $\mathrm{SnO}_{2}$ nanoparticle tetragonal structures and $\mathrm{CeO}_{2}$ nanoparticle cubic fluorite structures was exhibited by the generated $\mathrm{Ce}_{\mathrm{x}} \mathrm{Sn}_{1-\mathrm{x}} \mathrm{O}_{2}$ nanoparticles [61,62]. It must be noted that the XRD patterns of the samples did not reveal any contamination peak. Scherrer's formula can be applied to determine the nanoparticle crystal size $(D)$, as demonstrated as follows [6]:

$$
D=(0.9 \lambda) /(\beta \cos \theta),
$$

where the X-ray wavelength $(1.5406 \AA)$, the full width at half maximum, and the diffraction angle are respectively denoted by $\lambda, \beta$, and $\theta$. Thus, an increase in the $x$ value to $1.00 \mathrm{mmol}$ cerium nitrate hexahydrate determined an enlargement in crystallite size from 5 to $19 \mathrm{~nm}$. It can be deduced from the results that a rise in the $x$ value yields a diffraction peak with a greater intensity, as presented in Figure $5\left(\mathrm{x}_{0.20}-\mathrm{x}_{0.80}\right)$. Consequently, in relation to the nuclei, the enlarged particle size leads to an increase in crystalline volume ratio, thereby improving crystallinity [6,14]. 

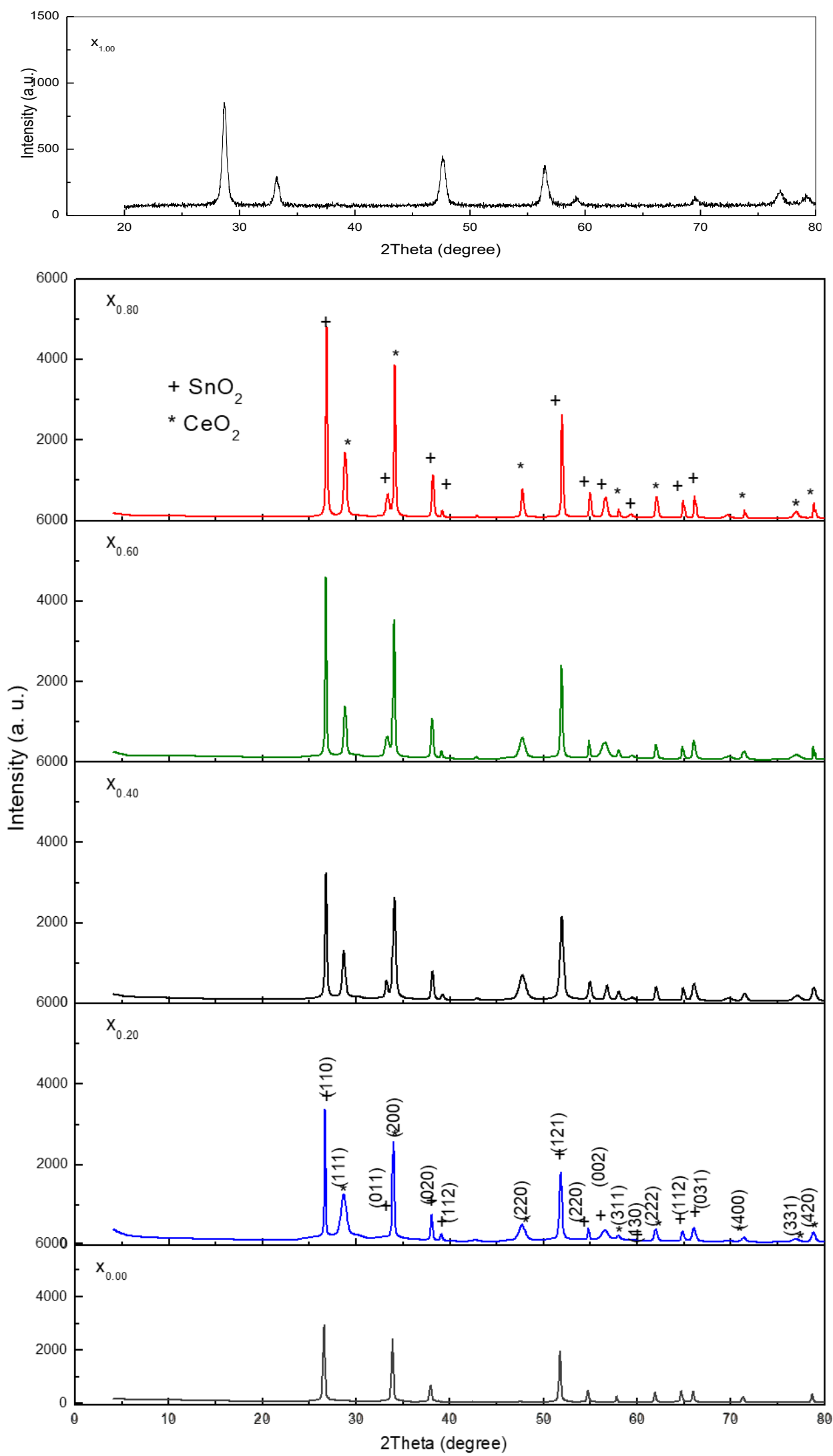

Figure 6. $\mathrm{XRD}$ patterns of $\left(\mathrm{x}_{0.00}\right) \mathrm{Ce}_{0.00} \mathrm{Sn}_{1.00} \mathrm{O}_{2},\left(\mathrm{x}_{0.20}\right) \mathrm{Ce}_{0.20} \mathrm{Sn}_{0.80} \mathrm{O}_{2},\left(\mathrm{x}_{0.40}\right) \mathrm{Ce}_{0.40} \mathrm{Sn}_{0.60} \mathrm{O}_{2},\left(\mathrm{x}_{0.06}\right) \mathrm{Ce}_{0.60} \mathrm{Sn}_{0.40} \mathrm{O}_{2},\left(\mathrm{x}_{0.08}\right)$ $\mathrm{Ce}_{0.80} \mathrm{Sn}_{0.20} \mathrm{O}_{2}$ and $\left.\left(\mathrm{x}_{1.00}\right) \mathrm{Ce}_{1.00} \mathrm{Sn}_{0.00} \mathrm{O}_{2}\right)$ nanoparticles calcined at $650{ }^{\circ} \mathrm{C}$. 


\subsection{FT-IR Analysis}

The FT-IR spectrum related to the $\mathrm{Ce}_{\mathrm{x}} \mathrm{Sn}_{1-\mathrm{x}} \mathrm{O}_{2}$ samples has been studied in the range of $80-4000 \mathrm{~cm}^{-1}$. Figure $7 \mathrm{a}-\mathrm{g}$ shows FT-IR spectra for the samples with different $x$ values after drying at $80^{\circ} \mathrm{C}$ and being calcined at $650^{\circ} \mathrm{C}$. In Figure $7 \mathrm{a}$ (sample after drying at $80^{\circ} \mathrm{C}$ only) the absorption bands at wavenumbers 3433,2954 , and $1673 \mathrm{~cm}^{-1}$ were attributed to $\mathrm{N}-\mathrm{H}, \mathrm{C}-\mathrm{H}$, and $\mathrm{C}=\mathrm{O}$ stretching vibrations [63]. The absorption band at $1418 \mathrm{~cm}^{-1}$ was attributed to $\mathrm{C}-\mathrm{H}$ bending vibration initiated in the methylene group, and the peak at $1272 \mathrm{~cm}^{-1}$ was assigned to the $\mathrm{C}-\mathrm{N}$ stretching vibration. The bands at 833,731 , and $620 \mathrm{~cm}^{-1}$ were mapped to $\mathrm{NO}^{3-}$ groups, with the vibrations generated by $\mathrm{C}-\mathrm{C}$ ring and $\mathrm{C}-\mathrm{N}=\mathrm{O}$ bending $[64,65]$. The absorption bands at 421 and $540 \mathrm{~cm}^{-1}$ were assigned to $\mathrm{Ce}-\mathrm{OH}$ band $\mathrm{Sn}-\mathrm{OH}$ vibrations. Figure $7 \mathrm{~b}-\mathrm{g}$ show the disappearance of these peaks due to broadband absorption for the samples calcinated at $650{ }^{\circ} \mathrm{C}$. The single absorption peak at $385 \mathrm{~cm}^{-1}$ in Figure $7 \mathrm{~b}$ was attributed to $\mathrm{Ce}-\mathrm{O}$, and the other single absorption peak at $491 \mathrm{~cm}^{-1}$ in Figure $6 \mathrm{~g}$ was attributed $\mathrm{Sn}-\mathrm{O}$. The double absorption peaks at 382, 373, $370,368 \mathrm{~cm}^{-1}$, and $487 \mathrm{~cm}^{-1}$ in Figure $7 \mathrm{c}-\mathrm{f}$ were attributed to $\mathrm{Ce}-\mathrm{O}$, and $\mathrm{Sn}-\mathrm{O}$, where the wavenumber values for the sample spectra changed when the $x$ values were increased. In regard to the $x$ value increase, this was proved by the variable crystallinity exhibited by the generated $\mathrm{Ce}_{x} \mathrm{Sn}_{1-\mathrm{x}} \mathrm{O}_{2}$ nanoparticles. All the bands characterizing the samples (i.e., $x=0.20-0.80$ ) were included in the range of the $\mathrm{Ce}-\mathrm{O}$ and $\mathrm{Sn}-\mathrm{O}$ stretching vibrations, confirming the purity of the synthesized $\mathrm{Ce}_{\mathrm{x}} \mathrm{Sn}_{1-\mathrm{x}} \mathrm{O}_{2}$ nanoparticles. Thus, the samples were free of additional impurities $[4,60]$.

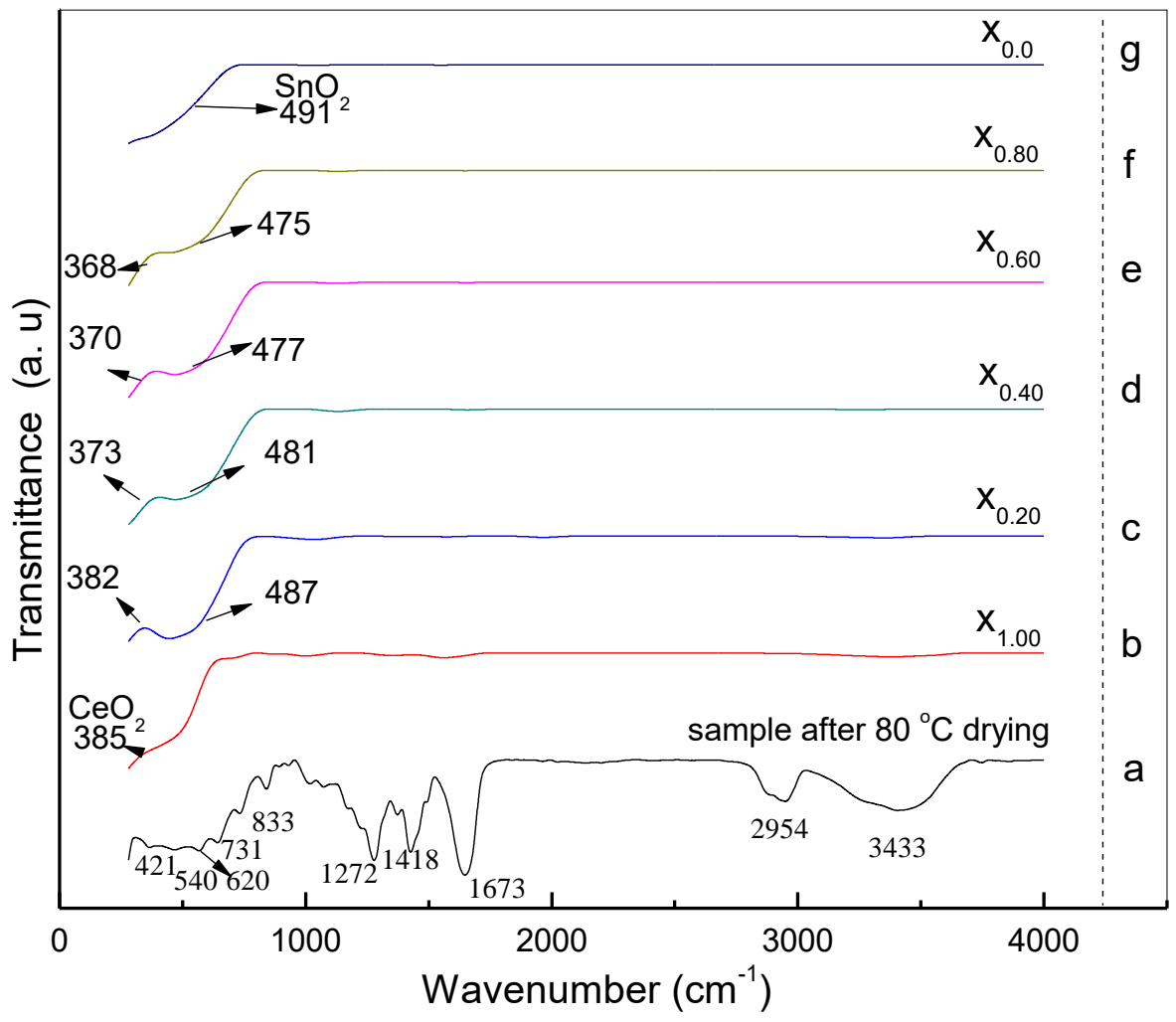

Figure 7. FTIR spectra of (a) the sample after drying at $80{ }^{\circ} \mathrm{C}\left((\mathbf{b}), \mathrm{x}_{1.00}\right) \mathrm{Ce}_{1.00} \mathrm{Sn}_{0.00} \mathrm{O}_{2},\left((\mathbf{c}), \mathrm{x}_{0.20}\right)$ $\mathrm{Ce}_{0.20} \mathrm{Sn}_{0.80} \mathrm{O}_{2}\left((\mathbf{d}), \mathrm{x}_{0.40}\right) \mathrm{Ce}_{0.40} \mathrm{Sn}_{0.60} \mathrm{O}_{2},\left((\mathbf{e}), \mathrm{x}_{0.60}\right) \mathrm{Ce}_{0.60} \mathrm{Sn}_{0.40} \mathrm{O}_{2},\left((\mathbf{f}), \mathrm{x}_{0.80}\right) \mathrm{Ce}_{0.80} \mathrm{Sn}_{0.20} \mathrm{O}_{2}$ and $((\mathrm{g})$, $\left.\mathrm{x}_{0.00}\right) \mathrm{Ce}_{0.00} \mathrm{Sn}_{1.00} \mathrm{O}_{2}$ nanoparticles calcined at $650{ }^{\circ} \mathrm{C}$.

\subsection{Bandgap Analysis}

The procedure underpinning the Kubelka-Munk function consists of mapping the square of this function, namely, $\left(\mathrm{F}\left(\mathrm{R}_{\infty}\right) \mathrm{hv}\right)^{2}$, in relation to the energy and extension of the linear portion of the curve to $F(R)^{2}=0$. As shown in Figure $8\left(x_{0.00}-x_{1.00}\right)$, the Kubelka- 
Munk function facilitates the calculation of energy bandgaps for nanoparticles according to the diffuse reflectance spectra associated with samples exposed to a temperature of $650{ }^{\circ} \mathrm{C}$. In this way, the band gap energy was generated for the oxide nanoparticles, with the energy bandgap values and $x$ values being inversely correlated. Quantum size effects explained the rise in the bandgap energy value, whereas the transitions among the partially suitable valance and conduction bands for $\mathrm{Ce}^{3+}$ ion $\mathrm{d}$-shell electrons explained the decrease in the band gap energy. Given the aspects addressed above, it is a complicated matter to eliminate the effect of particle size with regard to the band gap. Indeed, the material properties and band structure can be altered, where, owing to a particle size decrease, bandgap reduction is directly related to size enlargement. Disruption in the s-electron and p-electron conduction bands occurs at higher energy levels, leading to the possibility of superimposition when the particles are of a small size. In term of the Fermi-level distance, the larger the distance from the particle center, the lower the nuclear potential for electron conduction is. Hence, the absorption energy is equivalent to the conduction band energy in the case of transitions with permissible quantum numbers. In this work, band gap values were reduced whilst $x$ values were increased to make it easier to conduct a comparative analysis, as shown in Table 1; however, flawed states may be enhanced at elevated $\mathrm{x}$ values, resulting in a higher absorption coefficient. Furthermore, the characteristics of the optical nanomaterial and related electronic structures can be modified by the fields of the electron hole pairs generated by photon absorption.

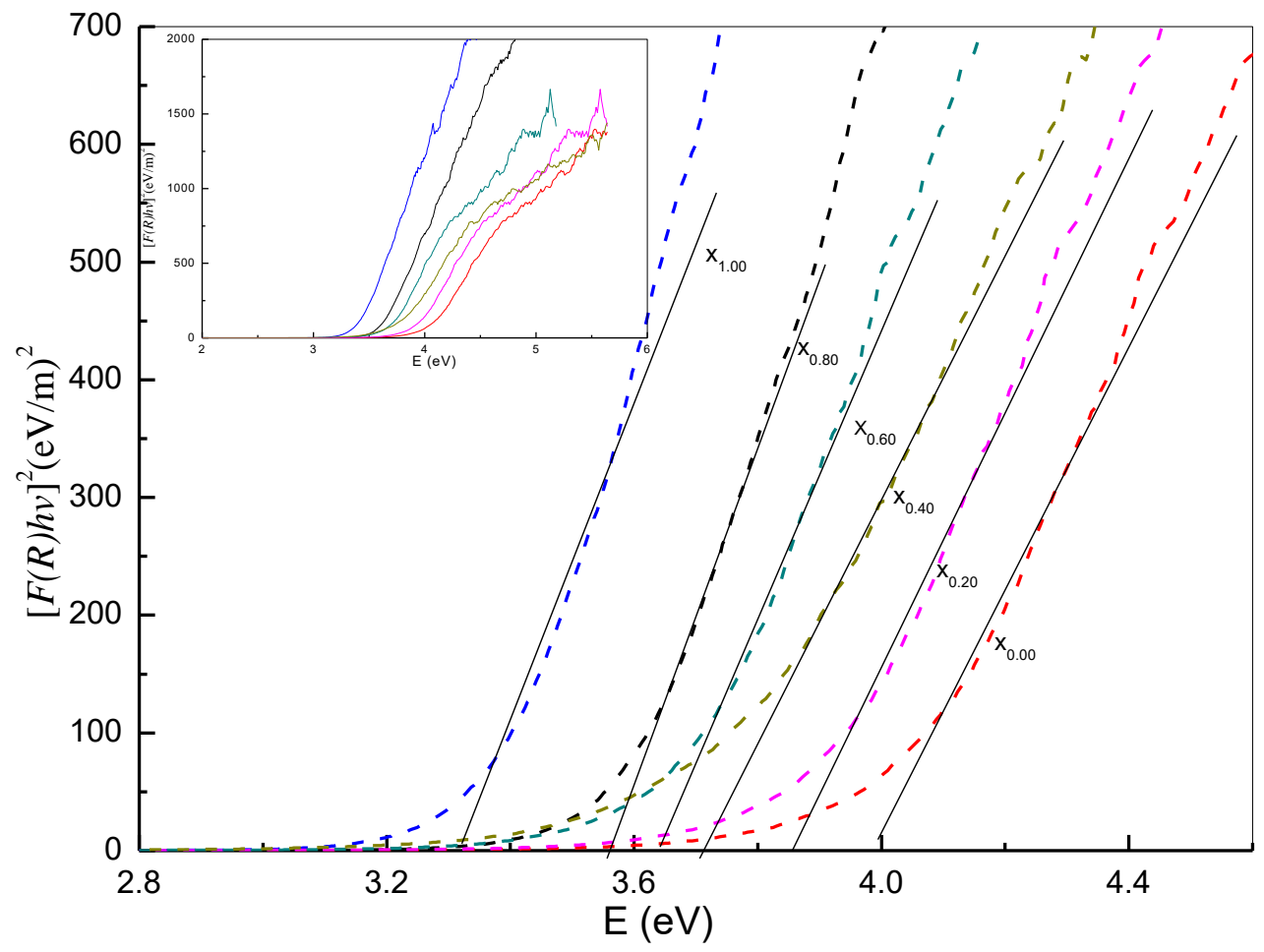

Figure 8. The energy bandgap of $\left(\mathrm{x}_{0.00}\right) \mathrm{Ce}_{0.00} \mathrm{Sn}_{1.00} \mathrm{O}_{2},\left(\mathrm{x}_{0.20}\right) \mathrm{Ce}_{0.20} \mathrm{Sn}_{0.80} \mathrm{O}_{2},\left(\mathrm{x}_{0.40}\right) \mathrm{Ce}_{0.40} \mathrm{Sn}_{0.60} \mathrm{O}_{2},\left(\mathrm{x}_{0.06}\right) \mathrm{Ce}_{0.60} \mathrm{Sn}_{0.40} \mathrm{O}_{2}$, $\left(\mathrm{x}_{0.08}\right) \mathrm{Ce}_{0.80} \mathrm{Sn}_{0.20} \mathrm{O}_{2}$, and $\left.\left(\mathrm{x}_{1.00}\right) \mathrm{Ce}_{1.00} \mathrm{Sn}_{0.00} \mathrm{O}_{2}\right)$ nanoparticles calcined at $650{ }^{\circ} \mathrm{C}$.

\section{Conclusions}

The results obtained in this paper have proven that calcination is an effective technique for the synthesis of $\mathrm{Ce}_{x} \mathrm{Sn}_{1-x} \mathrm{O}_{2}$ nanoparticles. In addition, $\mathrm{X}$-ray diffraction analysis revealed that, at every $x$ value, the $\mathrm{Ce}_{x} \mathrm{Sn}_{1-\mathrm{x}} \mathrm{O}_{2}$ nanoparticles exhibited a cubic fluorite structure for $\mathrm{CeO}_{2}$ and a tetragonal structure for $\mathrm{SnO}_{2}$. A direct correlation was established between the nanoparticle size and the $x$ value, with sizes ranging between 6 and $21 \mathrm{~nm}$ at $x$ values between 0.00 and 1.00. The double absorption peaks were attributed to $\mathrm{Ce}-$ 
$\mathrm{O}$ and $\mathrm{Sn}-\mathrm{O}$ and confirmed the purity of the $\mathrm{Ce}_{x} \mathrm{Sn}_{1-\mathrm{x}} \mathrm{O}_{2}$ nanoparticles. A shift in the wavenumber for the sample's nanoparticles spectra at increasing $\mathrm{x}$ values was documented. The novel thermal treatment method confirmed that the crystallinity of the $\mathrm{Ce}_{\mathrm{x}} \mathrm{Sn}_{1-\mathrm{x}} \mathrm{O}_{2}$ nanoparticles has been produced. Furthermore, the major vibrational modes displayed by Ce-O and Sn-O were identified via FT-IR analysis, while UV-vis absorption analysis revealed that, as the $x$ value increased, the energy band gap diminished. Moreover, the smaller particle size was derived from a lower $x$ value and the smaller energy band gap was derived from a higher $x$ value. It can thus be concluded that products at lower $x$ values can have antibacterial activity applications as the smaller particles can diffuse through the cell wall faster, while the products at higher $x$ values can have solar cell energy applications due to more electrons can be generated at the bigger particle size.

Author Contributions: N.M.A.-H. conceived and designed the experiments; N.M.A.-H., A.M.A.-G., M.A.S., and M.A.S. performed the experiments; N.M.A.-H., A.M.A.-G., M.A.S., M.H.F., and A.A.B., analyzed the data; H.K., E.M.B., Q.L., A.M.A., R.M.K., A.A.A.A., J.L., S.X., A.M.N., S.P., N.N., B.A.A.A. and J.W., contributed rea-gents/materials/analysis tools; N.M.A.-H., A.M.A.-G., and M.A.S. wrote the paper. All authors have read and agreed to the published version of the manuscript.

Funding: This research was supported in part by the Research Foundation for Advanced Talents of Dezhou University, in part by the Universiti Tenaga Nasional with Fund: Internal Research Grant Opex under grant RJO10517919/iRMC/Publication, in part by Taishan Scholars Program of Shandong Province (tsqn201812104), the Qingchuang Science and Technology Plan of Shandong Province (2019KJJ017), in part by researchers supporting project number (RSP-2021/348), King Saud University, Riyadh, Saudi Arabia, and in part by Universiti Teknologi Malaysia (UTM), Fellow Research Grant, Q.J130000.21A6.00P19.

Acknowledgments: This work was supported in part by the Research Foundation for Advanced Talents of Dezhou University, in part by the Universiti Tenaga Nasional with Fund: Internal Research Grant Opex under grant RJO10517919/iRMC/Publication, in part by Taishan Scholars Program of Shandong Province (tsqn201812104), the Qingchuang Science and Technology Plan of Shandong Province (2019KJJ017), in part by researchers supporting project number (RSP-2021/348), King Saud University, Riyadh, Saudi Arabia, and in part by Universiti Teknologi Malaysia (UTM), Fellow Research Grant, Q.J130000.21A6.00P19.

Conflicts of Interest: The authors declare no conflict of interest.

\section{References}

1. Yao, J.; Yang, M.; Duan, Y. Chemistry, biology, and medicine of fluorescent nanomaterials and related systems: New insights into biosensing, bioimaging, genomics, diagnostics, and therapy. Chem. Rev. 2014, 114, 6130-6178. [CrossRef]

2. Aziz, N.; Pandey, R.; Barman, I.; Prasad, R. Leveraging the attributes of mucor hiemalis-derived silver nanoparticles for a synergistic broad-spectrum antimicrobial platform. Front. Microbiol. 2016, 7, 1984. [CrossRef]

3. Marpu, S.B.; Benton, E.N. Shining light on chitosan: A review on the usage of chitosan for photonics and nanomaterials research Int. J. Mol. Sci. 2018, 19, 1795. [CrossRef] [PubMed]

4. Al-Hada, N.M.; Al-Ghaili, A.M.; Kasim, H.; Saleh, M.A.; Flaifel, M.H.; Kamari, H.M.; Baqiah, H.; Liu, J.; Jihua, W. The effect of PVP concentration on particle size, morphological and optical properties of cassiterite nanoparticles. IEEE Access 2020, 8 , 93444-93454. [CrossRef]

5. Al-Hada, N.M.; Kamari, H.M.; Saleh, M.A.; Flaifel, M.H.; Al-Ghaili, A.M.; Kasim, H.; Baqer, A.A.; Saion, E.; Jihua, W. Morphological, structural and optical behaviour of PVA capped binary $(\mathrm{NiO})_{0.5}\left(\mathrm{Cr}_{2} \mathrm{O}_{3}\right)_{0.5}$ nanoparticles produced via single step based thermal technique. Results Phys. 2020, 17, 103059. [CrossRef]

6. Al-Hada, N.M.; Kamari, H.M.; Abdullah, C.A.C.; Saion, E.; Shaari, A.H.; Talib, Z.A.; Matori, K.A. Down-top nanofabrication of binary $(\mathrm{CdO})_{\mathrm{x}}(\mathrm{ZnO})_{1-\mathrm{x}}$ nanoparticles and their antibacterial activity. Int. J. Nanomed. 2017, 12, 8309. [CrossRef]

7. Khan, I.; Saeed, K.; Khan, I. Nanoparticles: Properties, applications and toxicities. Arab. J. Chem. 2019, 12, 908-931. [CrossRef]

8. Han, Y.-H.; Kankala, R.K.; Wang, S.-B.; Chen, A.-Z. Leveraging engineering of indocyanine green-encapsulated polymeric nanocomposites for biomedical applications. Nanomaterials 2018, 8, 360. [CrossRef]

9. Veiseh, O.; Gunn, J.W.; Zhang, M. Design and fabrication of magnetic nanoparticles for targeted drug delivery and imaging. Adv. Drug Deliv. Rev. 2010, 62, 284-304. [CrossRef]

10. Kumar, K.S.; Choudhary, N.; Jung, Y.; Thomas, J. Recent advances in two-dimensional nanomaterials for supercapacitor electrode applications. ACS Energy Lett. 2018, 3, 482-495. [CrossRef] 
11. Ahmed, N.; Fessi, H.; Elaissari, A. Theranostic applications of nanoparticles in cancer. Drug Discov. Today 2012, 17, 928-934. [CrossRef] [PubMed]

12. Kabashin, A.V.; Singh, A.; Swihart, M.T.; Zavestovskaya, I.N.; Prasad, P.N. Laser-processed nanosilicon: A multifunctional nanomaterial for energy and healthcare. ACS Nano 2019, 13, 9841-9867. [CrossRef] [PubMed]

13. Al-Hada, N.M.; Kamari, H.M.; Baqer, A.A.; Shaari, A.H.; Saion, E. Thermal calcination-based production of SnO 2 nanopowder: An analysis of $\mathrm{SnO}_{2}$ nanoparticle characteristics and antibacterial activities. Nanomaterials 2018, 8, 250. [CrossRef]

14. Baqer, A.A.; Matori, K.A.; Al-Hada, N.M.; Shaari, A.H.; Saion, E.; Chyi, J.L.Y. Effect of polyvinylpyrrolidone on cerium oxide nanoparticle characteristics prepared by a facile heat treatment technique. Results Phys. 2017, 7, 611-619. [CrossRef]

15. Arabaci, A. Ceria-based solid electrolytes for IT-SOFC applications. Acta Phys. Pol. A 2020, 137, 530-534. [CrossRef]

16. Nithya, P.; Sundrarajan, M. Ionic liquid functionalized biogenic synthesis of AgAu bimetal doped $\mathrm{CeO}_{2}$ nanoparticles from justicia adhatoda for pharmaceutical applications: Antibacterial and anti-cancer activities. J. Photochem. Photobiol. B Biol. 2020, 202, 111706. [CrossRef]

17. Liu, Y.; Yang, J.; Wu, B.; Zhang, W.; Zhang, X.; Shan, C.; Liu, Q. $\mathrm{CeO}_{2} / \mathrm{Co}_{3} \mathrm{O}_{4}$ hollow microsphere: Pollen-biotemplated preparation and application in photo-catalytic degradation. Colloids Surf. A Physicochem. Eng. Asp. 2020, 586, 124193. [CrossRef]

18. Mohanty, B.; Chattopadhyay, A.; Nayak, J. Band gap engineering and enhancement of electrical conductivity in hydrothermally synthesized $\mathrm{CeO}_{2}-\mathrm{PbS}$ nanocomposites for solar cell applications. J. Alloys Compd. 2021, 850, 156735. [CrossRef]

19. Basavaraj, R.; Navami, D.; Deepthi, N.; Venkataravanappa, M.; Lokesh, R.; Kumar, K.S.; Sreelakshmi, T. Novel orange-red emitting Pr3+ doped $\mathrm{CeO}_{2}$ nanopowders for white light emitting diode applications. Inorg. Chem. Commun. 2020, $120,108164$. [CrossRef]

20. Xia, W.; Mao, J.; Xu, F.; Gong, M.; Tan, X.; Shen, Y.; Sun, L.; Xin, H.L. Atomic modulation engineering of hexagon-shaped CeO 2 nanocrystals by in situ sculpturing of an electron beam. J. Phys. Chem. C 2020, 124, 17006-17014. [CrossRef]

21. Pollitt, S.; Truttmann, V.; Haunold, T.; Garcia, C.; Olszewski, W.; Llorca, J.; Barrabes, N.; Rupprechter, G. The dynamic structure of Au38 (SR) 24 nanoclusters supported on $\mathrm{CeO}_{2}$ upon pretreatment and CO oxidation. ACS Catal. 2020, 10, 6144-6148. [CrossRef]

22. Dong, T.; Liu, W.; Ma, M.; Peng, H.; Yang, S.; Tao, J.; He, C.; Wang, L.; Wu, P.; An, T. Hierarchical zeolite enveloping Pd-CeO 2 nanowires: An efficient adsorption/catalysis bifunctional catalyst for low temperature propane total degradation. Chem. Eng. J. 2020, 393, 124717. [CrossRef]

23. dos Santos, A.; Dantas, T.; Costa, J.; Souza, L.; Soares, J.; Caldeira, V.; Araújo, A.; Santos, A. Formation of CeO 2 nanotubes through different conditions of hydrothermal synthesis. Surf. Interfaces 2020, 21, 100746. [CrossRef]

24. Matussin, S.; Harunsani, M.H.; Tan, A.L.; Khan, M.M. Plant-extract-mediated $\mathrm{SnO}_{2}$ nanoparticles: Synthesis and applications. ACS Sustain. Chem. Eng. 2020, 8, 3040-3054. [CrossRef]

25. Habte, A.G.; Hone, F.G.; Dejene, F.B. Effect of solution $\mathrm{pH}$ on structural, optical and morphological properties of $\mathrm{SnO}_{2}$ nanoparticles. Phys. B Condens. Matter 2020, 580, 411832. [CrossRef]

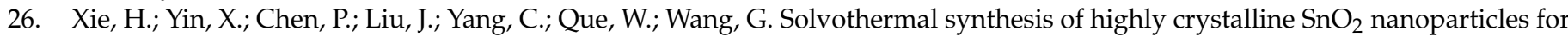
flexible perovskite solar cells application. Mater. Lett. 2019, 234, 311-314. [CrossRef]

27. Yun, A.J.; Kim, J.; Hwang, T.; Park, B. Origins of efficient perovskite solar cells with low-temperature processed $\mathrm{SnO}_{2}$ electron transport layer. ACS Appl. Energy Mater. 2019, 2, 3554-3560. [CrossRef]

28. Kumar, P.; Khadtare, S.; Park, J.; Yadav, B. Fabrication of leaf shaped $\mathrm{SnO}_{2}$ nanoparticles via sol-gel route and its application for the optoelectronic humidity sensor. Mater. Lett. 2020, 278, 128451. [CrossRef]

29. Letifi, H.; Litaiem, Y.; Dridi, D.; Ammar, S.; Chtourou, R. Enhanced photocatalytic activity of vanadium-doped $\mathrm{SnO}_{2}$ nanoparticles in rhodamine B degradation. Adv. Condens. Matter Phys. 2019, 2019, 2157428. [CrossRef]

30. Ravikumar, K.; Agilan, S.; Raja, M.; Marnadu, R.; Alshahrani, T.; Shkir, M.; Balaji, M.; Ganesh, R. Investigation on microstructural and opto-electrical properties of $\mathrm{Zr}$-doped $\mathrm{SnO}_{2}$ thin films for $\mathrm{Al} / \mathrm{Zr}$ : $\mathrm{SnO}_{2} / \mathrm{p}-\mathrm{Si}$ Schottky barrier diode application. Phys. $B$ Condens. Matter 2020, 599, 412452. [CrossRef]

31. Chen, K.; Chen, S.; Pi, M.; Zhang, D. $\mathrm{SnO}_{2}$ nanoparticles $/ \mathrm{TiO}_{2}$ nanofibers heterostructures: In situ fabrication and enhanced gas sensing performance. Solid-State Electron. 2019, 157, 42-47. [CrossRef]

32. Caldas, M.; Santos, A.C.; Veiga, F.; Rebelo, R.; Reis, R.L.; Correlo, V.M. Melanin nanoparticles as a promising tool for biomedical applications-A review. Acta Biomater. 2020, 105, 26-43. [CrossRef]

33. Kong, Z.; Liu, D.; Liu, X.; Fu, A.; Wang, Y.; Guo, P.; Li, H. One-pot decoration of graphene with $\mathrm{SnO}_{2}$ nanocrystals by an elevated hydrothermal process and their application as anode materials for lithium ion batteries. J. Nanosci. Nanotechnol. 2019, 19, 850-858. [CrossRef] [PubMed]

34. Hong, X.; Li, S.; Wang, R.; Fu, J. Hierarchical $\mathrm{SnO}_{2}$ nanoclusters wrapped functionalized carbonized cotton cloth for symmetrical supercapacitor. J. Alloys Compd. 2019, 775, 15-21. [CrossRef]

35. Reddy, C.S.; Murali, G.; Reddy, A.S.; Park, S.; In, I. GO incorporated $\mathrm{SnO}_{2}$ nanotubes as fast response sensors for ethanol vapor in different atmospheres. J. Alloys Compd. 2020, 813, 152251. [CrossRef]

36. Sun, L.; Wang, B.; Wang, Y. High-temperature gas sensor based on novel Pt single atoms@SnO ${ }_{2}$ nanorods@SiC nanosheets multi-heterojunctions. ACS Appl. Mater. Interfaces 2020, 12, 21808-21817. [CrossRef] [PubMed]

37. Choudhari, A.; Bhanvase, B.A.; Saharan, V.K.; Salame, P.H.; Hunge, Y. Sonochemical preparation and characterization of $\mathrm{rGO} / \mathrm{SnO}_{2}$ nanocomposite: Electrochemical and gas sensing performance. Ceram. Int. 2020, 46, 11290-11296. [CrossRef] 
38. Sagadevan, S.; Johan, M.; Bin, R.; Aziz, F.A.; Hsu, H.-L.; Selvin, R.; Hegazy, H.; Umar, A.; Algarni, H.; Roselin, S.L. Influence of Mn doping on the properties of Tin oxide nanoparticles prepared by Co-precipitation method. J. Nanoelectron. Optoelectron. 2019, 14, 583-592. [CrossRef]

39. Mamakhel, A.; Søndergaard, M.; Borup, K.; Iversen, B.B. Continuous flow hydrothermal synthesis of rutile $\mathrm{SnO}_{2}$ nanoparticles: Exploration of $\mathrm{pH}$ and temperature effects. J. Supercrit. Fluids 2020, 166, 105029. [CrossRef]

40. Lemarchand, A.; Rémondière, F.; Jouin, J.; Thomas, P.; Masson, O. Crystallization pathway of size-controlled SnO $\mathrm{S}_{2}$ nanoparticles synthesized via a nonaqueous sol-gel route. Cryst. Growth Des. 2020, 20, 1110-1118. [CrossRef]

41. Ali Baig, A.B.; Rathinam, V.; Ramya, V. Synthesis and investigation of Fe doped $\mathrm{SnO}_{2}$ nanoparticles for improved photocatalytic activity under visible light and antibacterial performances. Mater. Technol. 2020, 36, 623-635. [CrossRef]

42. Nurhasanah, I.; Safitri, W.; Windarti, T.; Subagio, A. The calcination temperature effect on the antioxidant and radioprotection properties of $\mathrm{CeO}_{2}$ nanoparticles. Reaktor 2018, 18, 22-26. [CrossRef]

43. Slavinskaya, E.; Zadesenets, A.; Stonkus, O.; Stadnichenko, A.; Shchukarev, A.; Shubin, Y.V.; Korenev, S.; Boronin, A. Thermal activation of $\mathrm{Pd} / \mathrm{CeO}_{2}-\mathrm{SnO}_{2}$ catalysts for low-temperature $\mathrm{CO}$ oxidation. Appl. Catal. B Environ. 2020, 277, 119275. [CrossRef]

44. Hassan, S.S.; Kamel, A.H.; Hassan, A.A.; Amr, A.E.-G.E.; El-Naby, H.A.; Elsayed, E.A. A SnO $2 / \mathrm{CeO}_{2}$ nano-composite catalyst for alizarin dye removal from aqueous solutions. Nanomaterials 2020, 10, 254. [CrossRef] [PubMed]

45. Liu, J.; Dai, M.; Wang, T.; Sun, P.; Liang, X.; Lu, G.; Shimanoe, K.; Yamazoe, N. Enhanced gas sensing properties of SnO 2 hollow spheres decorated with $\mathrm{CeO}_{2}$ nanoparticles heterostructure composite materials. ACS Appl. Mater. Interfaces 2016, 8, 6669-6677. [CrossRef] [PubMed]

46. Pattanaik, M.; Bhaumik, S.K. Adsorption behaviour of polyvinyl pyrrolidone on oxide surfaces. Mater. Lett. 2000, 44, 352-360. [CrossRef]

47. Al-Hada, N.M.; Saion, E.; Kamari, H.M.; Flaifel, M.H.; Shaari, A.H.; Talib, Z.A.; Abdullahi, N.; Baqer, A.A.; Kharazmi, A Structural, morphological and optical behaviour of PVP capped binary $(\mathrm{ZnO})_{0.4}(\mathrm{CdO})_{0.6}$ nanoparticles synthesised by a facile thermal route. Mater. Sci. Semicond. Process. 2016, 53, 56-65. [CrossRef]

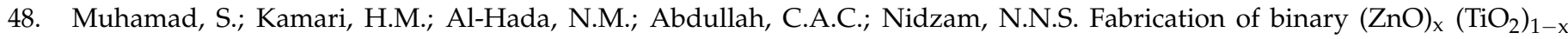
nanoparticles via thermal treatment route and evaluating the impact of various molar concentrations on the structure and optical behaviors. Appl. Phys. A 2020, 126, 1-15. [CrossRef]

49. Ghosh, G.; Naskar, M.K.; Patra, A.; Chatterjee, M. Synthesis and characterization of PVP-encapsulated ZnS nanoparticles. Opt. Mater. 2006, 28, 1047-1053. [CrossRef]

50. Koebel, M.M.; Jones, L.C.; Somorjai, G.A. Preparation of size-tunable, highly monodisperse PVP-protected Pt-nanoparticles by seed-mediated growth. J. Nanoparticle Res. 2008, 10, 1063-1069. [CrossRef]

51. Absi, E.; Saleh, M.A.; Al-Hada, N.M.; Hamzah, K.; Alhawsawi, A.M.; Banoqitah, E.M. Binary nickel and silver oxides by thermal route: Preparation and characterization. Appl. Phys. A 2021, 127, 606. [CrossRef]

52. Al-Hada, N.M.; Al-Ghaili, A.M.; Kasim, H.; Saleh, M.A.; Baqiah, H.; Liu, J.; Wang, J. Nanofabrication of $(\mathrm{Cr} 2 \mathrm{O} 3)_{\mathrm{x}}(\mathrm{NiO})_{1-\mathrm{x}}$ and the impact of precursor concentrations on nanoparticles conduct. J. Mater. Res. Technol. 2021, 11, 252-263. [CrossRef]

53. Hashem, M.; Saion, E.; Al-Hada, N.M.; Kamari, H.M.; Shaari, A.H.; Talib, Z.A.; Paiman, S.B.; Kamarudeen, M.A. Fabrication and characterization of semiconductor nickel oxide (NiO) nanoparticles manufactured using a facile thermal treatment. Results Phys. 2016, 6, 1024-1030. [CrossRef]

54. Gene, S.A.; Saion, E.B.; Shaari, A.H.; Kamarudeen, M.A.; Al-Hada, N.M. Fabrication and characterization of nanospinel ZnCr2O4 using thermal treatement method. In Advanced Materials Research; Trans Tech Publications Ltd.: Stafa-Zurich, Switzerland, 2015; pp. 301-307.

55. Baqer, A.A.; Matori, K.A.; Al-Hada, N.M.; Kamari, H.M.; Shaari, A.H.; Saion, E.; Chyi, J.L.Y. Copper oxide nanoparticles synthesized by a heat treatment approach with structural, morphological and optical characteristics. J. Mater. Sci. Mater. Electron. 2018, 29, 1025-1033. [CrossRef]

56. Al-Hada, N.M.; Kamari, H.M.; Shaari, A.H.; Saion, E. Fabrication and characterization of manganese-Zinc ferrite nanoparticles produced utilizing heat treatment technique. Results Phys. 2019, 12, 1821-1825. [CrossRef]

57. Al-Hada, N.M.; Saion, E.B.; Shaari, A.H.; Kamarudin, M.A.; Flaifel, M.H.; Ahmad, S.H.; Gene, A. A facile thermal-treatment route to synthesize the semiconductor CdO nanoparticles and effect of calcination. Mater. Sci. Semicond. Process. 2014, 26, 460-466. [CrossRef]

58. Kamari, H.M.; Al-Hada, N.M.; Saion, E.; Shaari, A.H.; Talib, Z.A.; Flaifel, M.H.; Ahmed, A.A.A. Calcined solution-based PVP influence on $\mathrm{ZnO}$ semiconductor nanoparticle properties. Crystals 2017, 7, 2. [CrossRef]

59. Lee, P.J.; Saion, E.; Al-Hada, N.M.; Soltani, N. A simple up-scalable thermal treatment method for synthesis of ZnO nanoparticles. Metals 2015, 5, 2383-2392. [CrossRef]

60. Baqer, A.A.; Matori, K.A.; Al-Hada, N.M.; Shaari, A.H.; Kamari, H.M.; Saion, E.; Chyi, J.L.Y.; Abdullah, C.A.C. Synthesis and characterization of binary $(\mathrm{CuO})_{0.6}\left(\mathrm{CeO}_{2}\right)_{0.4}$ nanoparticles via a simple heat treatment method. Results Phys. 2018, 9, 471-478. [CrossRef]

61. Lin, R.; Zhong, Y.-J.; Luo, M.-F.; Liu, W.-P. Structure and Redox Properties of $\mathrm{Ce}_{\mathrm{x}} \mathrm{Sn}_{1-\mathrm{x}} \mathrm{O}_{2}$ Mixed Oxides. Indian J. Chem. 2001, 40, 36-40.

62. Cao, J.-L.; Wang, Y.; Sun, G.; Zhang, Z.-Y. CuO/Ce $\mathrm{Sn}_{1-\mathrm{x}} \mathrm{O}_{2}$ catalysts: Synthesis, characterization, and catalytic performance for low-temperature CO oxidation. Transit. Metal. Chem. 2011, 36, 107-112. [CrossRef] 
63. Zakiyah, L.B.; Saion, E.; Al-Hada, N.M.; Gharibshahi, E.; Salem, A.; Soltani, N.; Gene, S. Up-scalable synthesis of size-controlled copper ferrite nanocrystals by thermal treatment method. Mater. Sci. Semicond. Process. 2015, 40, 564-569. [CrossRef]

64. Gene, S.A.; Saion, E.; Shaari, A.H.; Kamarudin, M.A.; Al-Hada, N.M.; Kharazmi, A. Structural, optical, and magnetic characterization of spinel Zinc chromite nanocrystallines synthesised by thermal treatment method. J. Nanomater. 2014, $2014,15$. [CrossRef]

65. Midala, I.H.; Kamari, H.M.; Al-Hada, N.M.; Tim, C.K.; Muhamad, S.; Hamza, A.M.; Abubakar, T.R.; Nuhu, I.M. Structural, morphological and optical properties of $(\mathrm{ZnO})_{0.2}\left(\mathrm{ZrO}_{2}\right)_{0.8}$ nanoparticles. Appl. Phys. A 2019, 125, 668. [CrossRef] 